\title{
IS IT POSSIBLE TO PREDICT FOOD RETAIL PRICES? EVIDENCE FROM LITHUANIAN MARKET
}

\author{
Artiom VOLKOV ${ }^{1}$, Mangirdas MORKŪNAS ${ }^{2}$, Viktorija SKVARCIANY $\mathbb{B D}^{3 *}$ \\ ${ }^{1,2}$ Lithuanian Institute of Agrarian Economics, V. Kudirkos g. 18-2, LT-03105 Vilnius, Lithuania \\ ${ }^{3}$ Department of Economics Engineering, Faculty of Business Management, \\ Vilnius Gediminas Technical University, Sauletekio al. 11, LT-10223 Vilnius, Lithuania \\ *E-mail: viktorija.skvarciany@vgtu.lt
}

\begin{abstract}
Purpose - the purpose of the article is to develop a model that could be used for estimating the level of the effect of the highlighted determinants on food retail prices.

Research methodology - the study is based on the obtained monthly data of food retail prices that covers the period from $2016 \mathrm{I} \mathrm{m}$. to 2018 XII m. (36 observations). Multiple regression modelling is used in order to create a model of food retail prices.

Findings - the results provide evidence that the most influential determinants are the price of the alternative products and purchasing power. It also contributes to scholarly thinking, stating, that it is possible to predict the future retail price of a particular product.

Research limitations - the limitation of the current study is that the proposed econometric model is sufficient for the Lithuanian market and ought to be modified if used in other countries.

Practical implications - the development model allows to predict/forecast the food retail prices which are crucial for households budget planning.

Originality/Value - the current study examines the main determinant of retail food prices. It laid a background for future researches, based on examining possibilities to forecast food prices. The research results contribute to classic economic views about market imperfections influence onto supply-demand equilibrium and unproductiveness of consumer illicit market.
\end{abstract}

Keywords: average retail price, food basket, consumer behaviour, purchasing power, production stock purchase price, agricultural subsector.

JEL Classification: Q11, L81.

Conference topic: Contemporary Issues in Economics Engineering.

\section{Introduction}

In the Eastern European countries, food has always been a subject of particular importance. Historical famines (Penter, 2018), malnutrition and food insufficiency have shaped an attitude to food as the most important commodity and a product of focal importance in Eastern Europeans viewpoint. Food prices coupled to costs for heating still dominate a typical Eastern European citizen's daily agenda (Rudzitis, Varanauskiene, Nestor, \& Kukk, 2016; Swedbank, 2018), an average Eastern European consumer spend the twice greater part of his budget onto food, compared to Western countries (Eurostat, 2017). Food prices even played a role in shaping political processes in Eastern Europe (Naimark \& Gibianskii, 2018), are subject to ongoing political debates before elections and serve as a measurement for the quality of life for poorer and more socially vulnerable part of society.

The possibility to predict food prices have been examined by a wide range of scholars (Akin, Dizbay, Gümüşoğlu, \& Güdücü, 2018; Andreyeva, Long, \& Brownell, 2010; Choi \& Entenmann, 2019; Khaydukova, Cetó, Kirsanov, del Valle, \& Legin, 2015; Maconachie, 2019; Zhang, Zang, Li, Ma, \& Liu, 2018; Zou, Xia, Yang, \& Wang, 2007). Although researchers are interested in a prediction of world prices for food products, it should be noticed, that because of various country's internal factors, movements in world food prices do not always have a mirror reflection in retail prices. This scientific vacuum and a practical phenomenon motivate us to conduct research on the possibility to predict food retail prices in the Lithuanian market. Consequently, the aim of the current research is to create an econometric 
model that could show the influence of the determinants that could be treated as predictors of retail prices of the food that is included in the main food basket.

However, this study has several research limitations. As a basis for the present research the price movements in Lithuanian market was chosen, hence, local peculiarities may influence the results and they should be applied only to countries with the similar historical, political and economic background (Baltic countries, Central and Eastern European countries).

The article consists of an introduction, theoretical background, where contradicting scientific theories on the possibility of predicting the future food prices are being presented, methodological part, where the econometrical model is being developed, and results and discussion chapter, where the results of a developed food price prediction model are being presented.

\section{Theoretical background}

Scientific literature, focusing on retail prices, could be divided into several different academic streams. One of the most popular and widely accepted is Theory of planned behaviour, which states, that the subjective norm, perceived behavioural control, and attitude affect consumer's intention, which in turn affects real behaviour (Ajzen, 1985). Therefore it is possible to predict the future consumer's choice, aggregate demand. This, coupled with easily predictable short term aggregate supply allow assessing the supply-demand equilibrium - retail price (Mendoza, Rydergren, \& Tampère, 2018; Xu \& Milanovic, 2016). Some other authors also support the planned behaviour theory (Chen, 2016; Khani Jeihooni, Kouhpayeh, Najafi, \& Bazrafshan, 2019; Paul, Modi, \& Patel, 2016; Yadav \& Pathak, 2016), although not extrapolating it into the aggregate demand. Other scholars appeal to aggregate demand and price sensitivity nexus (de Medeiros, Ribeiro, \& Cortimiglia, 2016; Wang, Lin, Liu, Sun, \& Wennersten, 2018; Xie, Zhang, Wei, Xia, \& Zhang, 2019). Price plays two different roles in consumers' assessments of product alternatives, namely, as a measure of sacrifice and an informational cue; the former refers to the number of money consumers need to spend and the latter refers to the quality and status inferred by ownership of the product (Hsu, Chang, \& Yansritakul, 2017). So if the aggregate demand increases, time for collection of information decreases, forcing the consumer to make a purchase decision on a higher price. This effect manifestoes itself independently from the product costs, World prices for a particular product, etc.

Sales and inventory scientists, employed in introducing new and more sophisticated pricing methods also argue, that at least in short period of time, retail price could be modelled and predicted (Ferrer, Oyarzún, \& Vera, 2012; Hendel \& Nevo, 2006). They argue, that exists a finite number of factors that are influencing retail prices (wholesale price, production costs, brand loyalty, market concentration level, price history, substitute product price level, aggregate demand, purchasing power of consumers, logistics features, best before period and etc.) and a combination of all these features determines the final retail price of a product. The challenge for scientists in that economic standpoint lays in a finding the right set of factors for each product (product group) and determining weights of these factors. After this has been accomplished, the future retail price should be reflected in an output of some created econometrical model. This scientific view has a limited success, as some products' future prices, such as commodities (Chen, Rogoff, \& Rossi, 2010; Ferraro, Rogoff, \& Rossi, 2015), oil (Baumeister \& Kilian, 2016; Hamilton, 2008), cacao, but fail to at least satisfactory forecast the future price of more sophisticated assets, such as real estate (Cain $\&$ Janssen, 1995; Mian, Sufi, \& Trebbi, 2015) or stock (MacKenzie, 2017) prices. The idea of forecasting retail prices using different factors and its combination augmented by the big data was researched by Bradlow, Gangwar, Kopalle, and Voleti (2017). Although it was found as a useful tool in forecasting lots of retailing indicators, its suitability for retail price prediction remains disputable.

The possibility to predict future prices has been contradicted by the classical economics theory proponents, who argue, that in imperfect markets due to hedonic consumer behavior, arises an implicit product market, which can be described as adding implicit characteristics in consumer's mind to existing product attributes to economic agents shifting his attention from observed prices of differentiated products and the specific amounts of characteristics associated with them (Greenstone, 2017). These differences between real and perceptive characteristics of a product add unpredictable perceived features, what are being valued by particular customers, willing to overpay for these implicit benefits, that are immeasurable so and impossible to forecast. The government also makes its credit to uncertainty in the prediction of future retail prices, especially products in the FMCG market. As shown by Poterba (1996) and enhanced by Ling, Osman, Muhammad, Yeng, and Jin (2016), the increase in state taxes increases prices, but decrease - do not affect retail price. Even the Government's contemplation about increasing tax burden encourages an unpredictable increase in price dynamics. Volatility is being augmented also by subsidies and other measures aimed at lowering income inequality (Zhao, Lin, \& Sun, 2016). A widely held view in macroeconomics is that menu costs of price adjustment give rise to aggregate price inertia and thus provide a mechanism through which changes in monetary policy have real effect is challenged by recent researches showing the absence of direct link between costs and price fluctuations (Midrigan, 2011), referring to consumer behavior and market imperfections as a perpetrators of this effect. 
A markup - retailers cost coverage and risk premium is also a subject of high volatility and adds complexity into retail price forecasting. The natural competitive market factors determine that it is economically unsound to use fixed markups in free flexible decentralized markets (Liu, Fry, \& Raturi, 2009).

These discrepancies in leading macroeconomics and management (consumer behaviour) theories motivate us to find out, which of these leading theories should be applied, researching the possibilities to predict retail food prices in Lithuania.

\section{Methodology}

The analysis of scientific literature showed that quantitative and qualitative indicators need to be used in order to predict retail prices of the food products, the latter, i.e. qualitative indicators, are difficult to predict and evaluate, as in many cases it depends on the behaviour of consumers. Quantitative, constantly changing and predictable indicators that affect the retail price of food products can be broken down by (Baležentis \& Kriščiukaitienè, 2016; Jurkènaitè, 2017; Melnikienè et al., 2018):

- the volume of the agricultural subsector, which raw materials (i.e. the number of livestock or planting area, number of holdings of the agricultural subsector, quantity of raw material purchased) are used for the production of the food product;

- production volume (total volume of food product produced in the country/region, productivity or level of production of coherent agricultural subsector);

- world food product price trends and purchase prices for the coherent raw material of agricultural subsector;

- import and export volumes of the food product;

- EU and national financial support (coupled and decoupled direct payments, other direct subsidies) for coherent agricultural subsectors;

- purchasing power (minimum wage or average wage).

All this suggests that an external global environment, internal production environment, internal and EU political environment, and consumer behavioural elements drive the retail food price in EU countries.

Factors assessed by qualitative methods may vary or not depending on the type of food product. In the case of first necessity, i.e. food products that belong to the main basket of goods, constant factors remain unchanged for a sufficiently long period (10-15 years). Such factors may include export conditions; the complexity of transportation; expiration date; Euro pallet value; the number of alternatives of a particular food product; turnover; brand and its promotion. We call it qualitative or semi-qualitative variables do not suitable for econometrical modelling. In order to minimize its influence onto final results, for our research we have chosen products of the first necessity, which consumers accept as almost homogeneous, buy constantly and frequently, so such qualitative variables as a brand name, product expiration date and etc. do not play a major role in retail price formation. All of these factors, with the exception of the number of alternatives, can be attributed to the retailer's or wholesaler's cost of a particular food product. The brand, the number of alternatives and their price determined also by consumer behaviour.

In the current research, the econometric model investigating the relationship between food product's retail price and its main determinants has been estimated (1). For the model development, log-log linear regression is chosen, i.e. outcome and all the predictors are log transformed.

$$
\begin{aligned}
& \ln R P_{t}^{i}=\alpha_{i}+\beta_{1 i} \ln A l t_{t}^{i}+\beta_{2 i} \ln P R M_{t}^{i}+\beta_{3 i} \ln A P u r_{t}^{i}+\beta_{4 i} \ln V o l_{t}^{i}+\beta_{5 i} \ln Y_{t}^{i}+ \\
& \beta_{6 i} \ln I m p_{t}^{i}+\beta_{7 i} \ln \operatorname{Exp}_{t}^{i}+\beta_{8 i} \ln P P_{t}^{i}+\beta_{9 i} \ln W P_{t}^{i}+\varepsilon_{i} E U P_{t}^{i} E U P_{t}^{i}
\end{aligned}
$$

where: $R P_{t}^{i}$ - monthly average retail price of $i$-th food product in time $t ; A l t_{t}^{i}$ - monthly average retail price of $i$-th food product alternative in time $t ; P R M_{t}^{i}$ - agricultural production stock (raw material) for the food product $i$ purchase price in time $t ; A P u r_{t}^{i}$ - monthly amount of purchased agricultural production stock for food product $i$ in time $t$ (in the case when food is different from agricultural production); $Y_{t}^{i}$ - yield of the agricultural subsector providing main stock for the food product $i$ per month in time $t ; V_{o l} l_{t}^{i}$ - volume of produced $i$-th food product per month in time $t$; Imp $p_{t}^{i}-$ imported volume of the food product $i$ per month in time $\mathrm{t}$; $\operatorname{Exp}_{t}^{i}$ - exported volume of the food product $i$ per month in time $t$; $P P_{t}^{i}$ - purchasing power (mean or minimum salary) of a country, which $i$-th food product's retail price is under evaluation; $W P_{t}^{i}$ (or $E U P_{t}^{i}$ ) - monthly average world (or EU) market price of the food product $i$ in time $t$.

Summing up, nine key quantitative indicators that could influence retail food price formation are listed.

$A l t_{t}^{i}$ - the indicator reflect the price of alternatives (if such exist). If a price of product alternatives is increasing, it is very likely the price of a researched product will also go up. 
$P R M_{t}^{i}$ - the indicator of the purchase price of the main raw material for food product $i$. Its influence on the retail price must be essential.

The $A P u r_{t}^{i}$ indicator shows the amount of agricultural production (raw materials) purchased from local farmers (producers); thus defining the capacity and need of certain agricultural subsector. Larger quantities lead to market certainty and lower risk of price fluctuations, but increasing demand may lead to rising retail prices of food product $i$.

The $\mathrm{Vol}_{t}^{i}$ indicator shows the capacity of the processors, i.e. the amount of food product $i$ produced per month. This can directly affect the retail price of food product $i$, as supply is affected by demand.

$Y_{t}^{i}$ stands for food products and their retail prices depend on the main raw material of agriculture from which they are made (rye bread, butter from milk, etc.). Therefore, the $Y_{t}^{i}$ indicator shows the level of development and productivity of the agricultural subsector, both in terms of more innovative farming methods or climatic conditions.

$\operatorname{Exp}_{t}^{i}$ and $\operatorname{Imp}_{t}^{i}$ stand for the indicators of import and export volumes have an impact on the food product $i$ retail price. Increased imports can lead to an increase in the retail price, while exports - on the contrary; however, in individual cases, it may be the other way around or the influence may be minimal.

The $P P_{t}^{i}$ indicator describes the level of economic development of a country through purchasing power. In theory, it can affect the retail price of food product $i$, first, the first necessity products of the main basket.

$W P_{t}^{i}\left(\right.$ or $\left.E U P_{t}^{i}\right)$ - indicator that affects the retail price of a food product $i$ within the country, especially when the product is not very specific and is not used only locally.

The survey focused on the 2016-2018 monthly retail prices of three main food products: butter, rye bread and whole eggs. Correlation analysis and multiple regressions have made it possible to determine which of the factors and indicators have a strong correlation with each other, and which are the factors of low dependency.

In order to ensure the reliability of the models, the following statistical parameters are used:

- Cook's $\left(D_{i}\right)$ distance is used in order to reveal if there are any outliers in the initial data.

- Determination coefficient $\left(R^{2}\right)$ is used in order to figure out which part of the dependent variable distribution could be described by the independent variables.

- Variance inflation factor $(V I F)$ is used for identification of multicollinearity problem.

- p-value is used in order to find out if the regression coefficients are statistically significant.

\section{Empirical findings}

Butter. In order to develop a regression model describing the factors influencing retail prices all the ten factors, mentioned in the methodology part, were used. After calculating the Cook's distance it was found out that there were no outliers in the data. However, there was a multicollinearity problem, hence, several factors were removed from the model. Since the multicollinearity problem was resolved the regression model was created (see (2)).

$$
\begin{aligned}
& \ln R P_{(i t)}^{\text {butter }}=-0.610+0.992 \ln \text { Alt }_{t}^{\text {butter }}+0.078 \ln \text { APur }_{t}^{\text {butter }}+ \\
& 0.045 \ln \text { Vol }_{t}^{\text {butter }}-0.043 \ln I m p_{t}^{\text {butter }}-0.029 \ln \operatorname{Exp}_{t}^{\text {butter }}-0.08 \ln W P_{t}^{\text {butter }} .
\end{aligned}
$$

The current regression model explains 98.6 per cent of butter retail prices $\left(R^{2}=0.986\right)$. According to the regression analysis with the 95 per cent confidence level, the main quantitative indicators, influencing butter retail trade (VAT is excluded), are Alt $_{t}^{i}$ - retail price of butter alternative (monthly retail prices of artificial butter were taken during the survey), amount of purchased milk in tones $A p u r_{t}, A P u r_{t}^{b u t t e r}$, volume of monthly butter production in the country, both butter import and export, and world butter price $W P_{t} . W P_{t}^{\text {butter }}$. The main influence on price formation is the change in the price of the alternative: as it increases, the price of butter increases the most. This factor identifies existing quite aggressive competition between the alternatives and also the fact, that typical Lithuanian consumer do not associate additional value to this product, brand name do not play an important role in a product choice, therefore supporting and substantiating our decision not to include nor static, nor dynamic qualitative factors of a retail food price formation mechanism into our econometrical model. Moreover, the amount of local milk bought by producers and the growing production of butter in the country are influencing the rising price of butter retail price, which can be justified by either the growing demand, or typical cost transmission chain, where all additional or increasing costs are being transmitted to a weaker chain. As it is being reflected in a retail price, it means, that consumer is in a weaker position and some intervention actions from the Government should be taken in order to balance the situation, trying to equally distribute the market power. Changes in import and export volumes cannot be assessed unambiguously, but a more pronounced change in foreign trade in butter sales results in lower retail prices for butter. This may indicate 
short-term butter surpluses in the market. One of the most controversial results of the model is the impact of global changes in butter prices on the retail price of butter within country, which is negative, i.e. as world prices fall, local retail prices are increasing. This may be partly due to the fact that the model does not include a consumer behavior element that has a significant impact on the retail prices.

Eggs. In order to develop a regression model describing the factors influencing retail prices the following factors were used: wholesale eggs price; EU market eggs price; eggs import volume; eggs export volume; consumer's purchase power. The other factors were skipped from that part of research according to the lack of statistical data. After calculating the Cook's distance it was found there was an outlier in the initial data $\left(D_{i}>1\right)$, which was eliminated from the data. Moreover, there was a multicollinearity problem, consequently, several factors were removed from the model. Since the multicollinearity problem was resolved the regression model was created (see (3)).

$$
\ln R P_{(i t)}^{\text {eggs }}=-6.665+0.811 \ln P P_{t}^{\text {eggs }}+0.489 \ln P R M_{t}^{\text {eggs }}+0.121 \ln \operatorname{Exp}_{t}^{\text {eggs }} .
$$

The presented regression equation explains 79.2 per cent of eggs retail price $\left(R^{2}=0.792\right)$ and all the coefficients are statistically significant ( $p$-value does not exceed 0.1 thresholds). The retail price of eggs in the country (based on monthly data) is influenced by purchasing power (monthly average salary), wholesale eggs price and eggs export volume. All of the above indicators have a positive impact on the retail price: the increase in the retail price of eggs in the country is induced by an increase of wholesale eggs prices, export volume increases and increases of average salary within the country. This result is both logical and economically rational. This price setting mechanism, based on purely macroeconomic rules reflects the absence of trade barriers, which could contradict World movements in prices to Lithuanian market, the signs of maturity of Lithuanian market, as a driving force in changes in retail prices is a consumers' purchasing power. This finding, contradicting evidence from the butter segment suggests that significant market imperfections in Lithuanian retail food market are restricted to only some market segments and are not applicable to the whole market. Given that eggs are the first essential commodity, it is natural, what purchasing power has a very important impact on the eggs retail price formation.

Rye bread. In order to develop a regression model describing the factors influencing retail prices all the ten factors, mention in the methodology part were used. After calculating the Cook's distance it was found out that there were no outliers in the data. However, there was a multicollinearity problem, hence, the factors that caused the appearance of that problem were removed from the analysis. The developed model is presented below (see (4)).

$$
\begin{aligned}
& \ln R P_{(i t)}^{\text {ryebread }}=-1.915+0.066 \ln \text { Vol }_{t}^{\text {ryebread }}+0.004 \ln \text { Exp }_{t}^{\text {ryebread }}+ \\
& 0.221 \ln P P_{t}^{\text {ryebread }}-0.152 \ln Y_{t}^{\text {ryebread }} .
\end{aligned}
$$

The presented regression equation explains 91.1 per cent of rye retail price $\left(R^{2}=0.991\right)$ and all the coefficients are statistically significant ( $\mathrm{p}$-value does not exceed 0.1 thresholds). The retail price of rye bread is influenced by the volumes of bread produced, the volume of exports, the purchasing power (monthly average salary in the country) and the yield of rye. Higher yields result in lower retail prices of rye bread. This result could be contradictory if the product was of wider use than a traditional one, but in this case, it is very logical in the context of economic theory. All other indicators as shown in the model have a positive impact on the retail price of rye bread, the increase of which increases rye bread prices. The only variance from classical economic thinking is in the fact, that higher volumes produced result higher prices. This fact can be explained by normally increasing demand, induced by the increasing purchasing power of consumers, it, in turn, influences overall inflation in a country.

\section{Conclusions}

It can be concluded, that the formation of the three food products retail prices were not based on the same indicators and their combinations. This shows that estimating retail pricing by quantitative or statistical methods alone, excluding the element of consumer behaviour, is difficult and may be of a little relevance. It contributes Nowotarski and Weron (2018), Sukiyono et al. (2018) and other theoreticians, stating, that there are no reliable and accurate models for forecasting future price movement directions, and it can be described as almost random. Our findings can be generalized, as although we did not include consumer behaviour prediction models into our research, we minimized its influence by choosing dairy food products of the first necessity, which are bought to satisfy basic needs of Lithuanian consumer, and do not have a high number of additional features, which may be accepted or treated by particular consumers differently, thus paving a way for price discrepancies paid for an implicit benefits.

Market imperfections existence in Lithuanian retail food market was also documented. Its significance was described by the facts contradicting classical economic views. As Lithuania is considered a small open economy, its inner market dynamics should reflect Worlds trends, but as noticed with butter case, retail prices not only do not mirror World price movements but choose opposite directions. In our opinion, such significant market imperfections leading to final consumers' losses should not be tolerated in the EU Members State, raising the initiative to Government to refine market regulation mechanisms. 


\section{Further research directions}

Econometrical model, which was employed in our research in order to identify possibilities of future food retail price forecasting, did not take into account qualitative factors influencing price movements. It would be beneficial to include both static (physical characteristics of researched food products, such as transportation amenities, expiry date, exhibition amenities and etc.) and dynamic (consumer behaviour, attitudes to different product alternatives, reactions to sales promotions and etc.) qualitative retail food price movement determinants.

The other scientifically valuable and important research direction - the assessment of the influence of revealed market imperfections onto retail food price dynamics in Lithuania. As it was documented, the significant market imperfections are able to overcome the prevailing trends of World market in Lithuanian food retail segment with the products that have a constant and growing demand in a World market (butter). It allows us to predict, that these market imperfections have even bigger influence onto products, what have a limited acceptance Worldwide and those price is being set by a Lithuanian supply-demand balance. The documentation of the role of such market imperfections in a free supply-demand based price setting mechanism could form a basis for the creation of a rationale to more strict market regulation mechanisms applied to products, which price cannot be checked by a World market.

\section{References}

Ajzen, I. (1985). From intentions to actions: a theory of planned behavior. In J. Kuhl \& J. Beckmann (Eds.), Action control (pp. 1139). Berlin, Heidelberg: Springer. https://doi.org/10.1007/978-3-642-69746-3_2

Akin, B., Dizbay, İ. E., Gümüşoğlu, Ş., \& Güdücü, E. (2018). The effect of perceived benefit on consumer based brand equity in online shopping Context. Ege Academic Review, 18(4), 579-588.

Andreyeva, T., Long, M. W., \& Brownell, K. D. (2010). The impact of food prices on consumption: a systematic review of research on the price elasticity of demand for food. American Journal of Public Health, 100(2), 216-222. https://doi.org/10.2105/AJPH.2008.151415

Baležentis, T., \& Kriščiukaitienè, I. (2016). Production and price risk in Lithuanian crop farming: scientific study. Vilnius. Retrieved from http://bit.do/eNvri

Baumeister, C., \& Kilian, L. (2016). Forty years of oil price fluctuations: why the price of oil may still surprise Us. Journal of Economic Perspectives, 30(1), 139-160. https://doi.org/10.1257/jep.30.1.139

Bradlow, E. T., Gangwar, M., Kopalle, P., \& Voleti, S. (2017). The Role of big data and predictive analytics in retailing. Journal of Retailing, 93(1), 79-95. https://doi.org/10.1016/j.jretai.2016.12.004

Cain, M., \& Janssen, C. (1995). Real estate price prediction under asymmetric loss. Annals of the Institute of Statistical Mathematics, 47(3), 401-414. https://doi.org/10.1007/BF00773391

Chen, Y.-C., Rogoff, K. S., \& Rossi, B. (2010). Can Exchange rates forecast commodity prices?* Quarterly Journal of Economics, 125(3), 1145-1194. https://doi.org/10.1162/qjec.2010.125.3.1145

Chen, Y. (2016). Bank capital and credit market competition: Will competitive pressure lead to higher capital levels? Journal of International Money and Finance, 69, 247-263. https://doi.org/10.1016/j.jimonfin.2016.07.006

Choi, H. S., \& Entenmann, S. K. (2019). Land in the EU for perennial biomass crops from freed-up agricultural land: A sensitivity analysis considering yields, diet, market liberalization and world food prices. Land Use Policy, 82, 292-306. https://doi.org/10.1016/j.landusepol.2018.11.023

de Medeiros, J. F., Ribeiro, J. L. D., \& Cortimiglia, M. N. (2016). Influence of perceived value on purchasing decisions of green products in Brazil. Journal of Cleaner Production, 110, 158-169. https://doi.org/10.1016/j.jclepro.2015.07.100

Eurostat. (2017). How much are households spending on food? Retrieved from https://ec.europa.eu/ eurostat/web/products-eurostatnews/-/DDN-20181204-1

Ferraro, D., Rogoff, K., \& Rossi, B. (2015). Can oil prices forecast exchange rates? An empirical analysis of the relationship between commodity prices and exchange rates. Journal of International Money and Finance, 54, 116-141. https://doi.org/10.1016/j.jimonfin.2015.03.001

Ferrer, J. C., Oyarzún, D., \& Vera, J. (2012). Risk averse retail pricing with robust demand forecasting. International Journal of Production Economics, 136(1), 151-160. https://doi.org/10.1016/j.ijpe.2011.09.026

Greenstone, M. (2017). The continuing impact of Sherwin Rosen's "Hedonic prices and implicit markets: product differentiation in pure competition.” Journal of Political Economy, 125(6), 1891-1902. https://doi.org/10.1086/694645

Hamilton, J. (2008). Understanding crude oil prices. Cambridge, MA. https://doi.org/10.3386/w14492

Hendel, I., \& Nevo, A. (2006). Sales and consumer inventory. The RAND Journal of Economics, 37(3), 543-561. https://doi.org/10.1111/j.1756-2171.2006.tb00030.x

Hsu, C.-L., Chang, C.-Y., \& Yansritakul, C. (2017). Exploring purchase intention of green skincare products using the theory of planned behavior: Testing the moderating effects of country of origin and price sensitivity. Journal of Retailing and Consumer Services, 34, 145-152. https://doi.org/10.1016/j.jretconser.2016.10.006

Jurkėnaitè, N. (2017). Paramos svarba kuriant tvarǔ žemès ūki Lietuvoje: mokslo studija. Vilnius. Retrieved from http://bit.do/eNvri

Khani Jeihooni, A., Kouhpayeh, A., Najafi, S., \& Bazrafshan, M.-R. (2019). Application theory of planned behavior on promotion of safe sexual behaviors among drug users. Journal of Substance Use, 24(3), 293-299.

https://doi.org/10.1080/14659891.2018.1562575 
Khaydukova, M., Cetó, X., Kirsanov, D., del Valle, M., \& Legin, A. (2015). A tool for general quality assessment of black tea-retail price prediction by an electronic tongue. Food Analytical Methods, 8(5), 1088-1092. https://doi.org/10.1007/s12161-014-9979-3

Ling, S. C., Osman, A., Muhammad, S., Yeng, S. K., \& Jin, L. Y. (2016). Goods and Services Tax (GST) compliance among malaysian consumers: the influence of price, government subsidies and income inequality. Procedia Economics and Finance, 35, 198-205. https://doi.org/10.1016/S2212-5671(16)00025-3

Liu, Y., Fry, M. J., \& Raturi, A. S. (2009). Retail price markup commitment in decentralized supply chains. European Journal of Operational Research, 192(1), 277-292. https://doi.org/10.1016/j.ejor.2007.08.036

MacKenzie, D. (2017). A material political economy: Automated Trading Desk and price prediction in high-frequency trading. Social Studies of Science, 47(2), 172-194. https://doi.org/10.1177/0306312716676900

Maconachie, R. (2019). Green grabs and rural development: How sustainable is biofuel production in post-war Sierra Leone? Land Use Policy, 81, 871-877. https://doi.org/10.1016/j.landusepol.2017.01.013

Melnikienè, R., Namiotko, V., Volkov, A., Šapolaitè, V., Gapšys, A., Bogdanov, A., ... Mikelionytè, D. (2018). Agricultural and food sector in Lithuania 2017. Vilnius. Retrieved from http://bit.do/eNvqZ

Mendoza, I., Rydergren, C., \& Tampère, C. M. J. (2018). Discovering regularity in mobility patterns to identify predictable aggregate supply for ridesharing. Transportation Research Record: Journal of the Transportation Research Board, 2672(42), 213-223. https://doi.org/10.1177/0361198118798720

Mian, A., Sufi, A., \& Trebbi, F. (2015). Foreclosures, house prices, and the real economy. The Journal of Finance, 70(6), 25872634. https://doi.org/10.1111/jofi.12310

Midrigan, V. (2011). Menu costs, multiproduct firms, and aggregate fluctuations. Econometrica, 79(4), 1139-1180. https://doi.org/10.3982/ECTA6735

Naimark, N. M., \& Gibianskii, L. (2018). The establishment of communist regimes in Eastern Europe, 1944-1949 (1st ed.). London: Routledge. https://doi.org/10.4324/9780429496585

Nowotarski, J., \& Weron, R. (2018). Recent advances in electricity price forecasting: A review of probabilistic forecasting. Renewable and Sustainable Energy Reviews, 81, 1548-1568. https://doi.org/10.1016/j.rser.2017.05.234

Paul, J., Modi, A., \& Patel, J. (2016). Predicting green product consumption using theory of planned behavior and reasoned action. Journal of Retailing and Consumer Services, 29, 123-134. https://doi.org/10.1016/j.jretconser.2015.11.006

Penter, T. (2018). From a Local Erfahrungsgeschichte of Holodomor to a global history of famines. Contemporary European History, 27(3), 445-449. https://doi.org/10.1017/S0960777318000310

Poterba, J. M. (1996). Retail price reactions to changes in state and local sales taxes. National Tax Journal, 49(2), 165-176. https://doi.org/10.1016/S0169-409X(02)00009-1

Rudzitis, E., Varanauskiene, J., Nestor, M., \& Kukk, M. (2016, April). Baltic household outlook. Retrieved from https://www.seb.lv/sites/default/files/web/files/webstorage/Analitiska-Info/Makroekonomika/en/Baltic-HouseholdOutlook_2016-04_en.pdf

Sukiyono, K., Nabiu, M., Sumantri, B., Novanda, R. R., Arianti, N. N., Sriyoto, S., .. Mustamam, H. (2018). Selecting an accurate cacao price forecasting model. Journal of Physics: Conference Series, 1114, 1-6. https://doi.org/10.1088/1742-6596/1114/1/012116

Swedbank. (2018). Tyrimas: kurioje iš Baltijos šalių sostiniu gyvenanti šeima išleidžia mažiausiai? Retrieved March 12, 2019 from https://bit.ly/2HVPgjY

Wang, Y., Lin, H., Liu, Y., Sun, Q., \& Wennersten, R. (2018). Management of household electricity consumption under price-based demand response scheme. Journal of Cleaner Production, 204, 926-938. https://doi.org/10.1016/j.jclepro.2018.09.019

Xie, J., Zhang, W., Wei, L., Xia, Y., \& Zhang, S. (2019). Price optimization of hybrid power supply chain dominated by power grid. Industrial Management \& Data Systems, 119(2), 412-450. https://doi.org/10.1108/IMDS-01-2018-0041

Xu, Y., \& Milanovic, J. V. (2016). Day-ahead prediction and shaping of dynamic response of demand at bulk supply points. IEEE Transactions on Power Systems, 31(4), 3100-3108. https://doi.org/10.1109/TPWRS.2015.2477559

Yadav, R., \& Pathak, G. S. (2016). Young consumers' intention towards buying green products in a developing nation: Extending the theory of planned behavior. Journal of Cleaner Production, 135, 732-739. https://doi.org/10.1016/j.jclepro.2016.06.120

Zhang, D., Zang, G., Li, J., Ma, K., \& Liu, H. (2018). Prediction of soybean price in China using QR-RBF neural network model. Computers and Electronics in Agriculture, 154, 10-17. https://doi.org/10.1016/j.compag.2018.08.016

Zhao, J., Lin, J., \& Sun, S. (2016). Price decision-making models in closed-loop supply chain based on government subsidies. In Proceedings of the 2016 International Conference on Intelligent Information Processing - ICIIP '16 (pp. 1-8). New York, New York, USA: ACM Press. https://doi.org/10.1145/3028842.3028854

Zou, H. F., Xia, G. P., Yang, F. T., \& Wang, H. Y. (2007). An investigation and comparison of artificial neural network and time series models for Chinese food grain price forecasting. Neurocomputing, 70(16-18), 2913-2923. https://doi.org/10.1016/j.neucom.2007.01.009 